\title{
IDENTIFIKASI CITRA TANDA TANGAN BERDASARKAN GRID ENTROPY DAN PCA MENGGUNAKAN MULTI LAYER PERCEPTRON
}

\author{
Agung WisnuAnggoro ${ }^{\# 1}$, Muhammad Zidny Naf' an ${ }^{\# 2}$, Elisa Usada ${ }^{\# 3}$ \\ FakultasTeknologiIndustri dan Informatika, InstitutTeknologi Telkom Purwokerto \\ Jl. D. I. Panjaitan No. 128, Purwokerto Selatan, Purwokerto, Jawa Tengah 53147, Indonesia. \\ ${ }^{1} \frac{15102004 @ \text { st3telkom.ac.id }}{2 \text { elisa@ittelkom-pwt.ac.id }}$
${ }_{3} \underline{\text { zidny@ittelkom-pwt.ac.id }}$
}

Accepted on April 11, 2019

\begin{abstract}
Abstrak
Tanda tangan merupakan suatu tanda yang menunjukkan keabsahan dari suatu dokumen legal yang sangat penting untuk dilakukan verifikasi apakah tanda tangan tersebut milik orang yang bersangkutan atau orang lain. Pada penelitian ini penulis melakukan identifikasi citra tanda tangan berdasarkan nilai fitur Grid Entropy dan ditambahkan algoritma Principal Component Analysisuntuk melakukan reduksi dimensi pada matriks fitur. Model pembelajaran yang digunakan yaitu Multi Layer Perceptron danCross Validationdengan skenario pengujian menggunakan nilai parameter yang berbeda pada hidden layer dan jumlah node dalam Multi Layer Perceptron. Hasil pengujian terbaik didapatkan dari pembelajaran dataset menggunakan 2 hidden layer dengan node sebanyak 40 node di setiap hidden layer, dari skenario tersebut didapatkan akurasi sebesar $87,22 \%$.
\end{abstract}

Keywords: cross validation, grid entropy, hidden layer, multi layer perceptron, principal component analysis, tanda tangan.

\section{PENDAHULUAN}

Tanda tangan merupakan tanda yang bertujuan sebagai lambang dari nama seseorang yang dituliskan menggunakan tangan orang itu sendiri sebagai penanda pribadi [1]. Peran tanda tangan dalam kehidupan sehari-hari sangatlah penting, tanda tangan merupakan sebuah identitas seseorang yang memiliki ciri khas tersendiri. Contoh tanda tangan saat melakukan absensi, absensi tidak dapat diwakilkan dikarenakan setiap orang memiliki tanda tangan yang berbeda. Perbedaan tanda tangan dapat dilihat secara jelas menggunakan indra penglihatan, tapi bagaimana jika ada tanda tangan tiruan. Jika terjadi hal tersebut maka perlu adanya identifikasi untuk mengetahui tanda tangan yang asli.

Identifikasi bertujuan untuk mengenali sebuah tanda tangan dan mengetahui ciri dari tanda tangan, dalam hal ini biometrika dapat dijadikan sebagai metode dasar dalam mengidentifikasi tanda tangan. Biometrika merupakan ilmu yang menerapkan statistika ke dalam biologi [1]. Biometrika sendiri terbagi menjadi 2 jenis, yaitu biometrika fisik dan biometrika perilaku [2]. Biometrika fisik yaitu biometrika yang berkaitan dengan aspek fisik, sebagai contoh yaitu sidik jari, wajah, dan retina mata. Sedangkan biometrika perilaku seperti 
kebiasaan sebuah yang dilakukan oleh seseorang sebagai contoh pola bicara, gerakan tubuh, tanda tangan ,dan lain-lain. Dalam hal ini tanda tangan termasuk bagian dari biometrika perilaku.

Pada umumnya identifikasi tanda tangan dapat dilakukan dengan menyaksikan secara langsung penulisan dari sebuah tanda tangan, namun dalam pengidentifikasian tanda tangan menggunakan komputer dibutuhkan suatu tahapan yaitu pengenalan pola tanda tangan, pengenalan pola tersebut dapat dilakukan dengan cara mengekstraksi ciri dari suatu tanda tangan. Salah satu cara mengekstraksi ciri tanda tangan yaitu menggunakan matriks citra. Berikut merupakan beberapa penelitian yang menggunakan matriks citra sebagai metode ekstraksi cirinya. Penelitian yang hanya menggunakan 1 metode ekstraksi ciri, sebagai contoh penelitian yang dilakukan oleh Naf'an dan Arifin [3] menggunakan nilai entropy dari setiap grid image(grid entropy) serta menggunakan Cross Validation dan Multi Layer Perceptron (MLP) sebagai metode pengenalan tanda tangan. Kemudian Wulanningrum, dkk [4] menggunakan Euclidean Distance untuk proses klasifikasi dan Principal Component Analysis (PCA) untuk proses ekstraksinya.

Adapun penelitian yang menggunakan lebih dari satu metode ekstraksi ciri, yaitu penelitian yang dilakukan oleh Pamungkas, dkk [5] menggunakan 2D-PCA dan 2D-LDA sebagai metode ekstraksi ciri tanda tangan dan menggunakan Euclidean Distance sebagai metode klasifikasinya. kemudian Adnan, dkk[6] yang menggunakan metode PCA dan LDA sebagai ekstraksi ciri dan menggunakan Euclidean Distance sebagai metode pengenalannya. Selain itu, Harahap, dkk [7] menggunakan PCA dan Kernel pada PCA (KPCA) sebagai ekstraksi ciri kemudian menggunakan Kohonen SOM sebagai pengenalannya.

Berdasarkan penelitian sebelumnya, metode yang digunakan untuk mengekstraksi ciri menggunakan nilai matriks citra memiliki hasil yang sangat beragam, metode tersebut diantaranya grid entropy, 2D-PCA, 2DLDA, PCA, KPCA dan sebagainya. Sehingga penelitian ini akan menggunakan 2 metode ekstraksi ciri yaitu grid entropy dan PCA, karena menurut penelitian yang dilakukan oleh Naf'an dan Arifin [3] faktor yang mempengaruhi tingkat akurasi yaitu banyaknya grid yang terlintas oleh coretan tanda tangan sehingga nilai entropy dari grid tersebut tidak nol (0) dan menurut Wulanningrum, dkk [4] PCA merupakan salah satu metode yang dapat digunakan untuk mengkonversi dan menormalisasi suatu citra. Oleh karena itu penggunaan grid entropy dan PCA memungkinkan untuk memberikan hasil yang lebih baik.

Dari uraian latar belakang di atas maka pada tugas akhir ini akan dilakukan penelitian dengan judul "Identifikasi Citra Tanda Tangan Berdasarkan Grid Entropy Dan PCA Menggunakan Multi Layer Perceptron". Kemudian untuk proses klasifikasi akan menggunakan Multi Layer Perceptron, menurut penelitian yang dilakukan oleh Odeh dan Khalil [8] Multi Layer Perceptron sangat handal ketika dilatih menggunakan data dengan jumlah yang besar dan struktur dari artificialneural network ini tergantung pada multilayer feed forward, dimana node-node yang berada pada suatu lapisan memiliki koneksi ke node-node di lapisan berikutnya dan seterusnya, akan tetapi node-node tersebut tidak memiliki koneksi dengan lapisan sebelumnya.

\section{LITERATURE REVIEW}

Penelitian mengenai pola tanda tangan hingga saat ini sudah banyak dilakukan dan metode yang digunakan juga beragam.Naf'an dan Arifin[3] melakukan penelitian identifikasi tanda tangan berdasarkan grid entropy dengan menggunakan metode Multi Layer Perceptron. Dalam penelitian tersebut terdapat 3 tahapan dalam mengidentifikasi tanda tangan yaitu preprocessing, ektraksi fitur/ciri tanda tangan, training, dan testing. Pada tahapan preprocessing terdapat proses image acquisition, cropping, penentuan Region Of Interest(ROI), dan merubah citra awal menjadi citra biner dan citra outline. Selanjutnya pada tahap ekstraksi fitur data citra yang sudah diubah dibagi menjadi beberapa bagian (grid image), kemudian dilakukan perhitungan entropy pada setiap grid yang bertujuan untuk mendapatkan nilai ciri. Kemudian pada tahap akhir yaitu melakukan data training, setelah didapatkan model dari proses data training maka dapat dilakukan pengujian pada proses data testing. Dari penelitian tersebut didapatkan akurasi tertinggi sebesar 97,78\%. Akurasi tersebut didapatkan dengan menggunakan grid image sebesar 8x8 (64 grid) dan menggunakan representasi citra outline.

Wulanningrum, dkk[4] melakukan penelitian mengenai tanda tangan dengan menggunakan metode Principal Component Analysis. Alur aplikasi pada penelitian ini dimulai dengan training data, diawali dengan memasukan nilai segmentasi data sampel kemudian memasukan nilai threshold. Setelah itu citra tanda tangan 
dilakukan preprocessing, pada tahapan dilakukan grayscalling dan partisi gambar. Selanjutnya memasukan nilai reduksi dimensi dan kemudian dilakukan ekstraksi ciri pada setiap partisi, hasil proses tersebut disimpan pada database. Proses pengujian (testing) sama dengan pelatihan (training), hasil dari testing data diklasifikasikan menggunakan metode Euclidean Distance. Dari proses tersebut didapatkan nilai akurasi sebesar 98\%. Nilai tersebut didapatkan dari pengujian dengan menggunakan nilaithreshold dari rentang nilai 0-255 dan menggunakan reduksi dimensi sebesar 20.

Pamungkas, dkk[5] melakukan penelitian mengenai tanda tangan dengan cara mengkomparasi dua metode yaitu 2D-PCA dan 2D-LDA. Proses training pada penelitian ini dilakukan dengan mengubah citra tanda tangan menjadi matriks, kemudian hasilnya di ekstraksi menggunakan kedua metode dan disimpan sebagai hasil dari data training. Untuk proses data trainingnya dilakukan dengan cara melakukan proses yang sama seperti pada proses data training kemudian hasilnya diklasifikasikan menggunakan Euclidean Distance. Dari penelitian tersebut didapatkan nilai akurasi rata-rata sebesar 78.27\% untuk metode 2D-PCA dan untuk metode 2D-LDA rata-rata $74.33 \%$.

Adnan, dkk[6] melakukan penelitian untuk melihat ubungan antara jumlah dimensi parameter exstraksi terhadap keakurasian pengenalan tanda tangan secara offline. Alur pemrosesan tanda tangan pada penelitian ini yaitu preprocessing, ekstraksi fitur, dan training-testing data. Pada tahap preprocessing dilakukan proses image resizing, normalisasi warna dan reshape gambar dengan cara merubah gambar 2 dimensi menjadi vektor 1 dimensi. Kemudian pada tahap ekstraksi fitur dilakukan dengan metode PCA dan LDA dengan memperhatikan ukuran dimensinya antara 10-60 dimensi, hasil ekstraksi fitur ini adalah sebuah parameter yang akan digunakan pada proses testing data. Pada tahap akhir yaitu mengklasifikasikan hasil data testing menggunakan metode Euclidean Distance. Dari penelitian tersebut didapatkan nilai keakuratan sebesar 83,09\% dengan merubah dimensi dari 540 dimensi ke 40 dimensi.

Harahap, dkk [7] melakukan penelitian mengenai tanda tangan yaitu mengidentifikasi tanda tangan menggunakan Kohonen SOM dengan menggunakan metode Principal Component Analysis. Tahapan identifikasi pada penelitian dimulai dengan preprocessing gambar dengan melakukan cropping dan scalling, kemudian pada proses ekstraksi fitur dilakukan dengan metode PCA dan KPCA dan kemudian diklasifikasi dengan metode Kohonen SOM, selanjutnya hasil disimpan pada database sebagai hasil training data. Pada tahapan testing dilakukan preprocessing dan ekstraksi fitur sama seperti pada proses training, kemudian hasilnya dilakukan pengujian SOM. Dari proses tersebut didapatkan nilai akurasi tertinggi sebesar 94,76\% dari kombinasi KPCA dan Kohonen SOM.

\section{A. Dataset Tanda Tangan}

\section{RESEARCH METHOD}

Dalam penelitian ini data yang digunakan merujuk pada penelitian sebelumnya yaitu pada penelitian yang dilakukan oleh Arifin dan Naf'an[3], penelitian tersebut menggunakan data citra dari 30 responden, setiap responden melakukan tanda tangan sebanyak 30 kali sehingga didapatkan data sebanyak 900 citra tanda tangan dengan format TIFF(Temporary Instruction File Format).

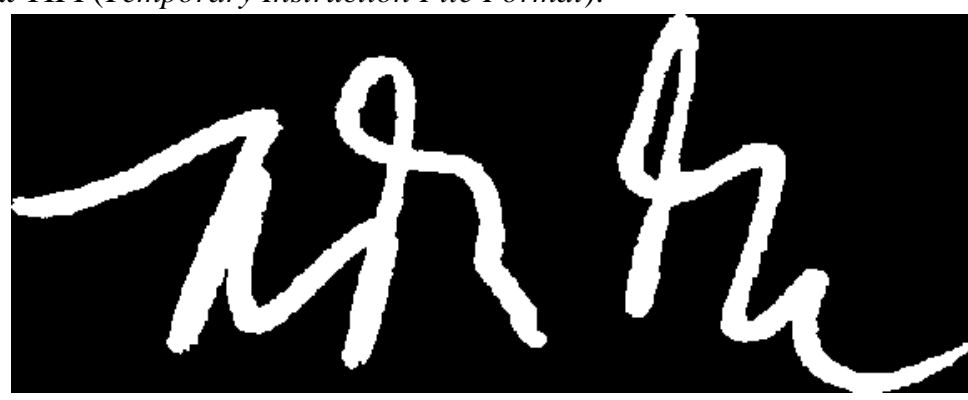

Gambar 1. Contoh dataset tanda tangan

\section{B. Metode Pembelajaran Tanda Tangan}

Metode Pembelajaran Tanda Tangan yang digunakan pada penelitian ini terdiri dari 3 tahap, yaitu` prapemrosesan, ekstraksi ciri, dan training-testing, sebagaimana yang ditunjukkan Gambar 2. 


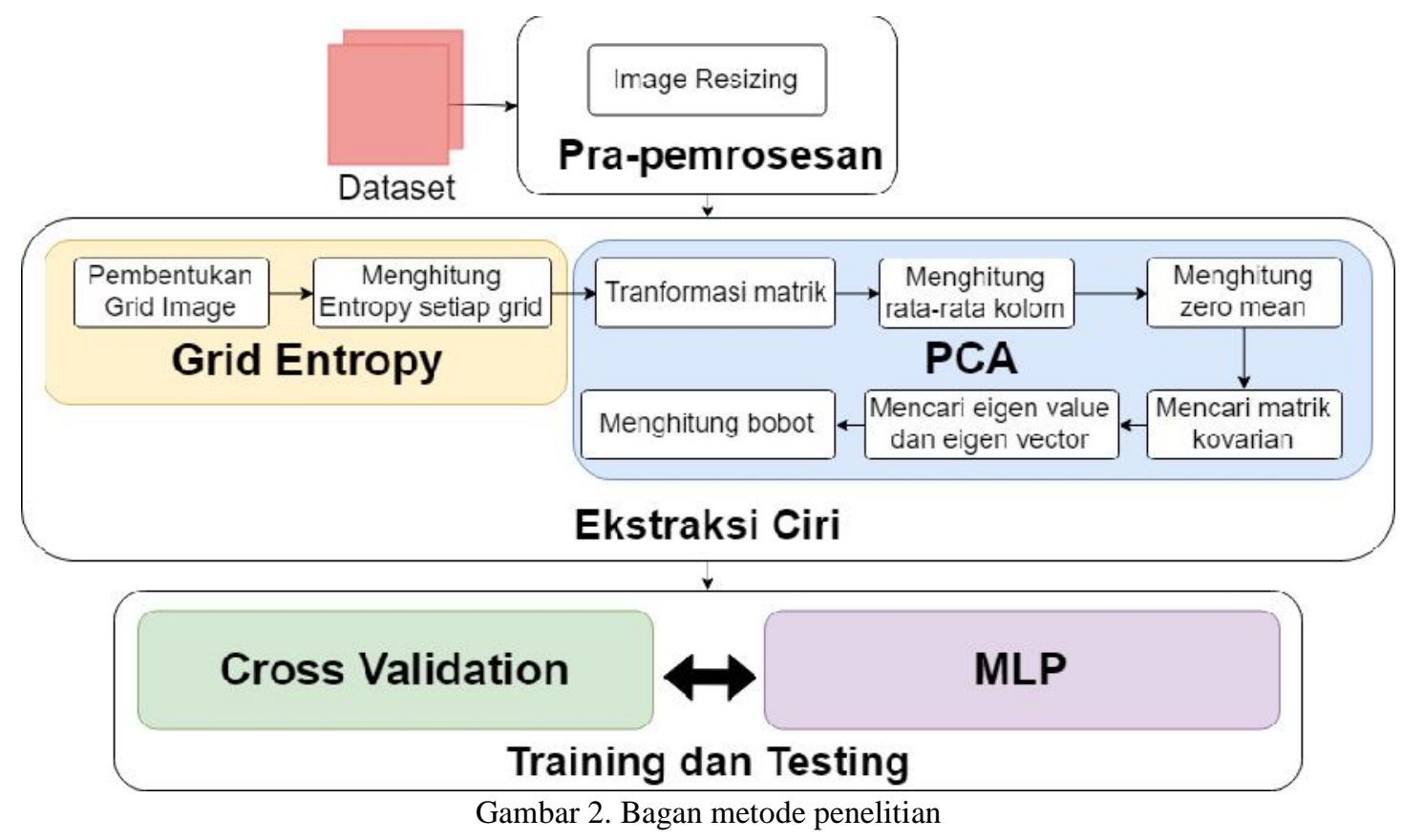

a) Pra-pemrosesan

Pada tahapan ini hanya dilakukan image resizing dikarenakan data tanda tangan atau dataset sudah melalui pra-pemrosesan sebelumnya, seperti Gaussian filter, ROI (Region Of Interest) image, dan inverse image. Pada tahapan ini semua gambar akan diresize dari ukuran asli menjadi ukuran 1000x1000 pixel, tahapan ini dilakukan menggunakan tools MATLAB. Berikut merupakan contoh resizing image:

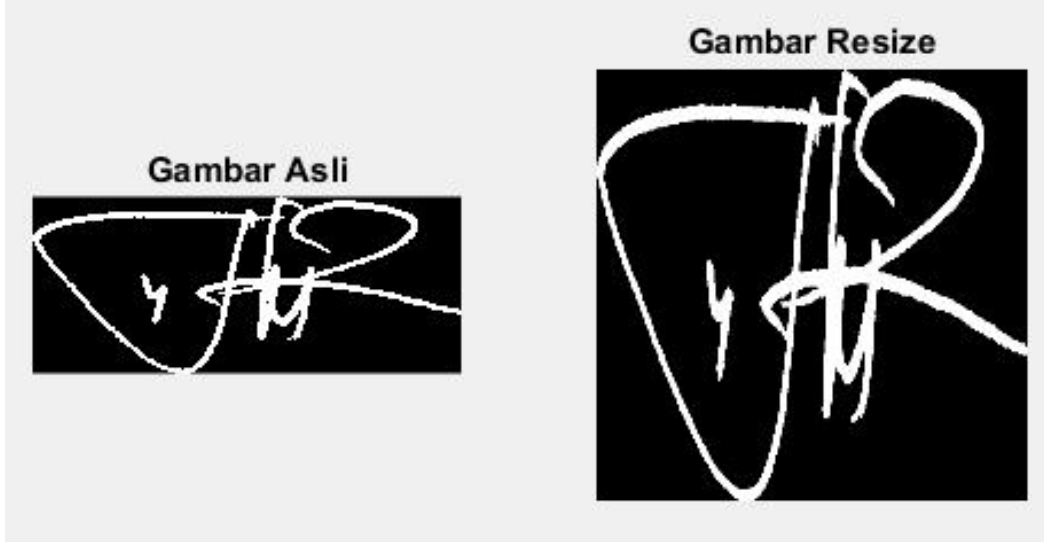

Gambar 3. Tanda Tangan Tahap Pra-Pemrosesan

b) Ekstraksi Ciri

Pada tahapan ini terdapat 2 proses ekstraksi ciri yaitu Grid Entropy dan PCA, tahapan ini dilakukan menggunakan tools yaitu MATLAB. Pada ekstraksi ciri ini penggunaan Grid Entropy bertujuan untuk mendapatkan nilai entropy dari setiap grid image yang ada sedangkan PCA bertujuan untuk mengurangi dimensi dari grid image dan mendapatkan ciri yang sudah direduksi dimensinya.

1) Grid Entropy

Proses pertama kali pada tahapan ini yaitu membagi image kedalam beberapa grid, kemudian dari hasil pembagian grid tersebut akan dicari entropy setiap grid. Rumus yang digunakan mengacu pada penelitian [2], rumusnya adalah sebagai berikut: 
$H=-\sum_{k=0}^{L-1} p_{r}\left(r_{k}\right) \log _{2} p_{r}\left(r_{k}\right)$

$\mathrm{k}$ merupakan nilai dalam sebuah citra dengan jangkauan dari 0 hingga $\mathrm{L}-1$, dengan $\mathrm{L}$ merupakan banyaknya nilai level keabuan citra, sedangkan $p_{r}\left(r_{k}\right)$ menunjukkan nilai probabilitas kemunculan nilai $\mathrm{k}$ pada citra yang didapatkan dari rumus berikut:

$p_{r}\left(r_{k}\right)=\frac{n_{k}}{M N}$

Dengan $n_{k}$ adalah jumlah kemunculan nilai k pada seluruh piksel, $\mathrm{M}$ adalah jumlah baris citra, dan $\mathrm{N}$ adalah jumlah kolom citra [2]. Berikut gambaran pembagian grid pada image sebesar 40x40 grid (1600 grid) serta hasil perhitungan entropy pada grid image:

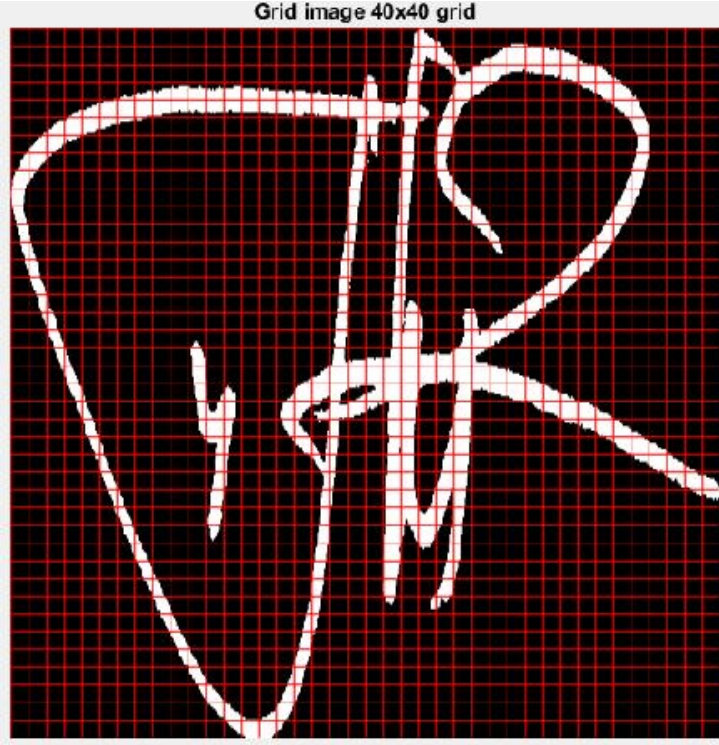

Gambar 4. Simulasi grid image

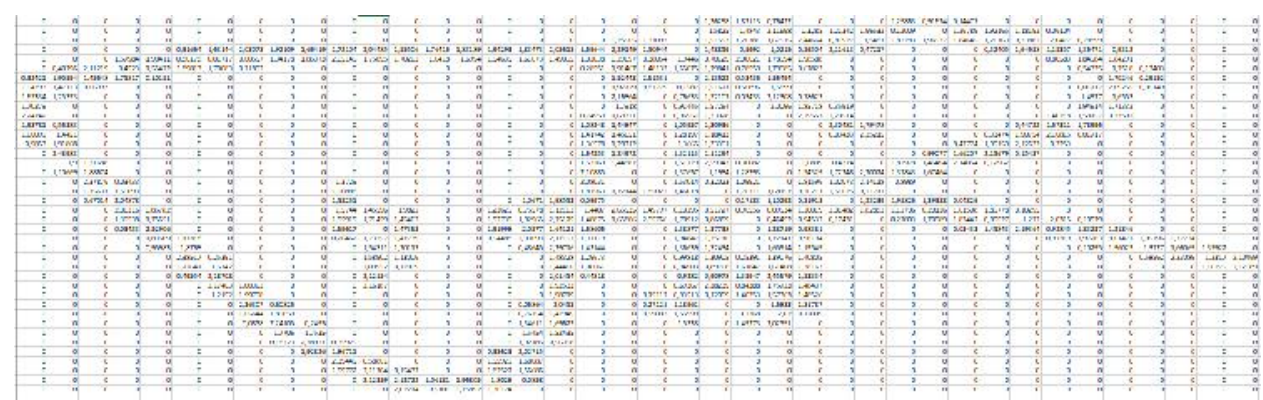

Gambar 5. Nilai grid entropy

2) $\mathrm{PCA}$

Pada ekstraksi menggunakan PCA hasil dari grid entropy akan dirubah menjadi matrik 1 baris untuk setiap tanda tangan sehingga dari dimensi 40x40 berubah menjadi 1x1600. Dengan jumlah tanda tangan sebanyak 900 maka dimensi dataset adalah 900x1600. Berikut merupakan gambaran transformasi matriknya: 

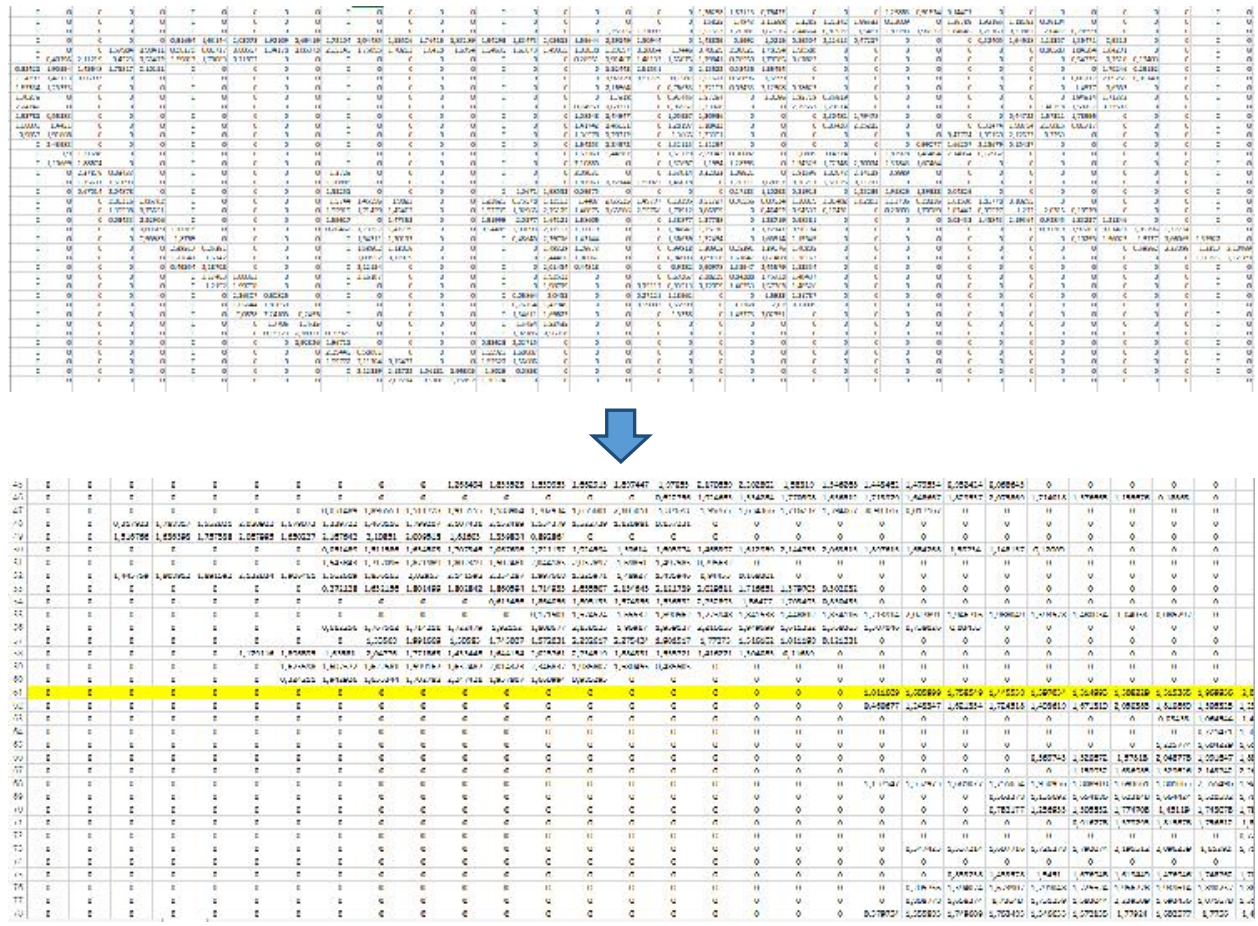

Gambar 5. Hasil ekstraksi PCA

Kemudian setelah didapatkan matrik grid entropy dataset dengan dimensi 900x1600 selanjutnya yaitu mencari nilai rata-rata kolom, setiap rumus yang digunakan mengacu pada buku[9]. Berikut persamaanya:

$\mu=\left[\begin{array}{llll}\frac{\sum_{k=1}^{m} f(k)_{k, 1}}{m} & \frac{\sum_{k=1}^{m} f(k)_{k, 2}}{m} & \cdots \frac{\sum_{k=1}^{m} f(k)_{k, n}}{m}\end{array}\right]=\left[\begin{array}{lll}\mu_{1,1} & \mu_{1,2} \cdots & \mu_{1, n}\end{array}\right]$

Dari persamaan (3) maka rata-rata kolom yang dihasilkan memiliki dimensi 1x1600 kemudian disalin sebanyak jumlah baris dataset, maka dimensi rata-rata kolom menjadi 900x1600.

Setelah didapatkan rata-rata kolom dengan dimensi 900x1600 kemudian mencari nilai zero mean yaitu dengan mengurangi matrik dataset dengan rata-rata kolom, berikut persamaanya:

$\emptyset=f(k)_{h, w}-\mu$

Selanjutnya yaitu mencari matrik kovarian dataset, dengan mengkalikan matrik zero mean dengan matrik zero mean yang ditranspose, kemudian dibagi dengan total baris dikurang 1 maka akan didapatkan matrik kovarian dengan dimensi 900x900. Jika dibuat permamaan adalah sebagai berikut:

$\mathrm{C}=\frac{1}{n-1} \emptyset * \emptyset^{T}$

Dari persamaan (5) maka hasil yang didapat adalah matrik covarian dengan dimensi 900x900.

Selanjutnya mencari nilai eigen value dan eigen vector dari matrik kovarian. Untuk mendapatkan nilai eigen vector dan eigen value yaitu dilakukan dengan menggunakan tools MATLAB, berikut merupakan persamaan:

$C * P=\lambda * P$

Selanjutnya yaitu mencari nilai bobot dataset dengan cara mengalikan matriks entropy dataset berdimensi 900x1600 dengan matrik proyeksi dataset yang berdimensi 1600x900, berikut merupakan persamaanya:

$W=f(k)_{m, n} * V_{h, w}$

Dari persamaan (7) maka hasil yang didapat adalah matrik bobot dengan dimensi 900x900. 
c) Training dan Testing

Pada tahapan training dan testing dilakukan pada tools jupyter. Pada penggunaan cross validation dataset dibagi menjadi 10 fold dengan iterasi $10 \mathrm{kali}$, kemudian pembagian data tersebut akan dibagi menjadi data training dan data testing dengan pembagian yang berbeda pada setiap iterasi. Untuk pembagianya setiap iterasi adalah sebagai berikut:

Tabel 1. Simulasi pembagian data training dan testing pada K-Fold

\begin{tabular}{|c|c|c|c|c|c|c|c|c|c|c|}
\hline Iterasi & Fold 1 & Fold 2 & Fold 3 & Fold 4 & Fold 5 & Fold 6 & Fold 7 & Fold 8 & Fold 9 & Fold 10 \\
\hline 1 & & & & & & & & & & \\
\hline 2 & & & & & & & & & & \\
\hline 3 & & & & & & & & & & \\
\hline 4 & & & & & & & & & & \\
\hline 5 & & & & & & & & & & \\
\hline 6 & & & & & & & & & & \\
\hline 7 & & & & & & & & & & \\
\hline 8 & & & & & & & & & & \\
\hline 9 & & & & & & & & & & \\
\hline 10 & & & & & & & & & & \\
\hline
\end{tabular}

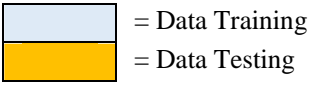

Dari pembagian data training dan data testing pada setiap iterasi dilakukan pembelajaran dengan menggunakan MLP, maka hasil yang didapat ada nilai akurasi rata-rata dari 10 iterasi.

\section{A. Skenario Pembelajaran}

\section{RESULTS AND DISCUSSION}

Proses pembelajaran ini dilakukan dengan menggunakan parameter yang berbeda dengan tujuan untuk mendapatkan nilai akurasi tertinggi.

Tabel 2. Skenario pembelajaran

\begin{tabular}{ccl}
\hline Skenario ke- & Jumlah Hidden Layer & Node setiap Hidden Layer \\
\hline 1 & 2 & 10 dan 10 \\
\hline 2 & 2 & 20 dan 10 \\
\hline 3 & 2 & 20 dan 20 \\
\hline 4 & 2 & 30 dan 20 \\
\hline 5 & 2 & 30 dan 30 \\
\hline 6 & 2 & 40 dan 30 \\
\hline 7 & 2 & 40 dan 40 \\
\hline 8 & 3 & 10,10 dan 10 \\
\hline 9 & 3 & 20,10 dan 10 \\
\hline 10 & 3 & 20,20 dan 10 \\
\hline 11 & 3 & 20,20 dan 20 \\
\hline 12 & 3 & 30,20 dan 20 \\
\hline 13 & 3 & 30,30 dan 20 \\
\hline 14 & 3 & 30,30 dan 30 \\
\hline 15 & 3 & 40,30 dan 30 \\
\hline 16 & 3 & 40,40 dan 30 \\
\hline 17 & 3 & 40,40 dan 40 \\
\hline
\end{tabular}




\section{B. Hasil Pembelajaran}

Dari skenaria pada tabel 2 maka didapatkan nilai akurasi sebagai berikut:

Tabel 3. Hasil akurasi

\begin{tabular}{cc}
\hline Skenario ke- & Akurasi \\
\hline 1 & $71,78 \%$ \\
\hline 2 & $76,00 \%$ \\
\hline 3 & $82,56 \%$ \\
\hline 4 & $83,44 \%$ \\
\hline 5 & $86,22 \%$ \\
\hline 6 & $86,78 \%$ \\
\hline 7 & $\mathbf{8 7 , 2 2 \%}$ \\
\hline 8 & $64,11 \%$ \\
\hline 9 & $66,56 \%$ \\
\hline 10 & $74,00 \%$ \\
\hline 11 & $77,33 \%$ \\
\hline 12 & $79,11 \%$ \\
\hline 13 & $80,33 \%$ \\
\hline 14 & $82,44 \%$ \\
\hline 15 & $83,44 \%$ \\
\hline 16 & $84,78 \%$ \\
\hline 17 & $85,89 \%$ \\
\hline
\end{tabular}

Pada tabel 3 dapat dilihat nilai akurasi tertinggi didapatkan dari skenario pembelajaran ke-7 dengan menggunakan 2 hidden layer yang memiliki node sebanyak 40 pada setiap hidden layer. Maka kondisi dari skenario pembelajaran ke-7 dijadikan sebagai model untuk diterapkan menggunakan Android, yaitu menggunakan 2 hidden layer dengan node sebanyak 40 di setiap hidden layer.

\section{CONCLUSION}

Nilai akurasi tertinggi didapatkan pada penggunaan hidden layer sebanyak 2 layer dengan menggunakan node masing-masing layer sebanyak 40 node, dari hasil skenario pembelajaran pada tabel 3 dapat disimpulkan jika semakin banyak layer dan node yang gunakan belum tentu akan menghasilkan akurasi yang lebih tinggi.

Saran-saran untuk penelitian lanjutan, yaitu menghindari adanya bayangan saat mengambil foto tanda tangan, mempersingkat proses identifikasi dengan menggunakan tools yang lebih efektif, serta menggunakan metode klasifikasi dan ekstraksi ciri yang lain untuk mendapatkan hasil akurasi yang lebih baik.

\section{REFERENCES}

[1] Pusat Bahasa Departemen Pendidikan Nasional, Kamus Bahasa Indonesia, vol. 1. 2008.

[2] J. Arifin and M. Z. Naf 'an, "Verifikasi Tanda Tangan Asli Atau Palsu Berdasarkan Sifat Keacakan (Entropi)," J. Infotel, vol. 9, no. 1, pp. 130-135, 2017.

[3] M. Z. Naf' an and J. Arifin, “Identifikasi Tanda Tangan Berdasarkan Grid Entropy Menggunakan Multi Layer Perceptron,” J. Infotel, vol. 9, no. 2, pp. 172-176, 2017.

[4] R. Wulanningrum, E. Utami, and A. Amborowati, "Implementasi Principal Component Analysis Untuk," Semin. Nas. Teknol. Inf. dan Multimed. 2014, vol. 1, no. 1, pp. 31-36, 2014.

[5] D. P. Pamungkas, E. Utami, and A. Amborowati, "Komparasi Pengenalan Citra Tanda Tangan dengan Metode 2D-PCA dan 2D-LDA," Citec J., vol. 2, no. 4, pp. 341-354, 2015.

[6] F. Adnan, "Investigasi Hubungan antara Jumlah Dimensi Parameter Extraksi Terhadap Keakurasian Pengenalan Tanda Tangan Secara Offline," Semin. Nas. Teknol. Inf. Komun. Terap. 2012, vol. 1, no. 1, pp. 370-376, 2012.

[7] H. Mawaddah, A. Mahmud Husein, and A. Dharma, "BERBASIS PRINCIPAL COMPONENT ANALYSIS," Semin. Nas. APTIKOM, vol. 1, no. 1, pp. 3-7, 2017.

[8] S. Odeh and M. Khalil, "Apply Multi-Layer Perceptrons Neural Network for Off-line signature verification and recognition," Int. J. Comput. Sci. Issues, vol. 8, no. 6, pp. 261-266, 2011.

[9] A. Muntasa, PENGENALAN POLA; Aplikasi untuk Pengenalan Wajah, Analisis Tekstur Obyek, Pengenalan Plat Nomor Kendaraan dan Segmentasi Pembuluh Darah. Yogyakarta: GRAHA ILMU, 2015. 